\title{
EKSISTENSI BAHASA JAWA DALAM WACANA MEME
}

\author{
Dewi Untari \\ Universitas Sebelas Maret Surakarta \\ dewi.untari70@gmail.com
}

\begin{abstract}
This study aims to describe the forms of Javanese used in Javanese meme; forms of Javanese meme; and function of the Javanese meme readers. Type of this research is a descriptive qualitative research. Data source this study is the Javanese memes in instagram Dagelan_Jowo accounts. Data taken by using purposive sampling technique. The results of research that the Javanese meme is one of the form of the Javanese that is still used today. The meme as a form of expression of the communities that serve as entertainment, as well as containing the message. Meme with a social theme most often occurs because of social phenomena is often done by the community. The meme using a variety of a ngoko Javanese which is neutral.
\end{abstract}

Keywords: meme, Javanese, a variety of a ngoko

\begin{abstract}
Abstrak
Penelitian ini bertujuan untuk mendeskripsikan bentuk-bentuk bahasa Jawa yang digunakan dalam meme berbahasa Jawa; bentuk-bentuk meme berbahasa Jawa; dan fungsi meme berbahasa Jawa terhadap masyarakat pembacanya. Jenis penelitian ini adalah penelitian deskriptif kualitatif. Sumber data penelitian ini adalah meme-meme berbahasa Jawa di akun instagram Dagelan_Jowo. Data diambil dengan menggunakan teknik purposive sampling. Hasil penelitian yaitu bahwa meme berbasa Jawa tersebut adalah salah satu wujud atau bentuk bahasa Jawa yang masih digunakan saat ini. Meme tersebut sebagai bentuk ekspresi masyarakat yang berfungsi sebagai hiburan, sekaligus mengandung pesan. Meme dengan tema sosial paling sering muncul karena fenomena sosial tersebut sering dilakukan oleh masyarakat. Meme tersebut menggunakan bahasa Jawa ragam ngoko yang sifatnya netral.
\end{abstract}

Kata Kunci: meme, bahasa Jawa, ragam ngoko

\section{Pendahuluan}

Bahasa Jawa adalah bahasa yang sangat kaya karena memiliki banyak kosakata, misalnya perihal sakit perut, dalam bahasa Indonesia hanya ada kosakata mulas/ sakit perut saja, namun dalam kosakata bahasa Jawa yaitu sebah (perut penuh dengan makanan dan terasa penuh), mules (ketika diare), mlilit (dirasakan jika telat makan), senep (terasa seperti perut ditusuk-tusuk). Tidak hanya itu, bahasa Jawa memiliki dasanama artinya satu benda/ sesuatu memiliki banyak nama. Misalnya kata merah, dalam bahasa Jawa yaitu abang, abrit, rekta, jingga, dan jenar. Hal demikian menunjukkan betapa kayanya bahasa Jawa jika dibandingkan dengan bahasa lain seperti bahasa Indonesia. Bahkan kosakata-kosakata bahasa Indonesia juga cukup banyak menyerap dari kosakata bahasa Jawa, misalnya wadhah, kinclong, mumpung, dan lain-lain. 
Bahasa Jawa masih dipertahankan pemakaiannya dalam berbagai situasi. Bahasa ini masih bertahan karena penuturnya masih berusaha mempertahankannya dari nenek moyangnya yang mengajarkannya. Penutur bahasa ini lebih banyak menggunakannya dalam situasi non-formal (sehari-hari). Ada juga digunakan dalam acara formal seperti upacara kedaerahan (acara pernikahan, acara lelayu, dsb). Namun, jika dibandingkan frekuensi penggunaannya, tetap akan terlihat lebih banyak frekuensi ketika digunakan dalam kehidupan sehari-hari. Rata-rata orang dalam situasi formal kurang lebih 8 jam, dibandingkan dengan situasi nonformal 16 jam. Maka bahasa yang dipakai sehari-hari lah yang akan lebih dominan dalam hidup seseorang. Mereka yang masih mempertahankan bahasa Jawa dalam kehidupan sehari-hari dan kemudian tidak hanya dalam bentuk lisan saja, melainkan pemertahanannya dituangkan dalam wujud karya, misalnya dalam bentuk meme.

Meme bisa disajikan dengan menggunakan berbagai bahasa, baik bahasa nasional (bahasa Indonesia), bahasa internasional (seperti bahasa Inggris), bahkan bahasa lokal, seperti bahasa Jawa. Meme yang dipilih dalam penelitian ini adalah meme berbahasa Jawa. Hal tersebut dikarenakan frekuensi kemunculan meme berbahasa Jawa cukup banyak di media sosial. Hal itu disebabkan pula penutur bahasa Jawa yang cakupannya luas yaitu 84,3 juta penutur/ urutan ke-11 di dunia (Ethnolugue dalam Pratiwi Wini, 2012) sehingga potensi mereka untuk membuat meme berbahasa Jawa itu sangat besar. Ada akun-akun instagram yang memang dikhususkan untuk mengupload meme-meme berbahasa Jawa seperti dagelan_jowo, dagelanjowo, guyonanjowo, lawak_jowo, ketoprak_jowo, dagelan. jowo, jowobaperann, geguyonan_jowo, tumblrjowol2, tumblrsuroboyoan_, dagelanjowo_ campur, dan leluconjowo. Selain itu, peneliti sendiri juga merupakan penutur aktif bahasa Jawa, sehingga peneliti lebih mudah untuk memahami arti bahasa/ makna dalam teks meme.

Istilah meme diserap langsung dari bahasa Yunani Kuno: $\mu і \dot{\mu} \mu \alpha$ - mímēma, yang artinya imitasi/tiruan. Meme berisi tulisan meme (verbal) dan gambar (viasual) yang merupakan ekspresi atau representasi dari tulisan pada meme tersebut. Tulisan meme biasanya terdiri dari monolog dan dialog. Monolog dan dialog tersebut menunjukkan bahwa seolaholah meme tersebut berbicara/bertutur. Tulisan dalam meme pada awalnya hanya sekedar bentuk ekspresi, kemudian ada beberapa penelitiaan terdahulu yang menunjukkan bahwa tulisan tersebut tidak hanya sekedar bentuk ekspresi, melainkan juga memberi informasi dan memiliki fungsi. Salah satu fungsi tersebut adalah sebagai kritik sosial suatu keadaan/ peristiwa. Selain itu, menurut Kenfitria Diah Wijayanti (2015, p.203), yang menyatakan bahwa tuturan yang terdapat dalam meme ternyata mengandung maksud berupa pesan. Menurut Rosa Redia Pusanti dan Haryanto (2015, p.8), meme tidak hanya mengandung humor tetapi juga sentilan, kritik serta ungkapan akan gagasan-gagasan mengenai fenomena terkini yang sedang hangat.

Persebaran meme sekarang ini sangat pesat yaitu melalui media sosial. Media sosial adalah sebuah media bersosial tanpa harus bertatap muka, melainkan dengan alat yaitu komputer atau smartphone yang dibantu dengan jaringan internet dan aplikasi. Menurut Purbo dalam Prihatna (2005, p.7), internet dengan berbagai aplikasi, seperti web, VoIP, dan e-mail pada dasarnya merupakan media yang digunakan untuk mengefisienkan proses komunikasi. Media sosial sangat beragam jenisnya, seperti facebook, whatsapp, bbm (blackberry messanger), instagram, line, dan twitter. Semua itu ada di smartphone (HP cerdas) atau PC/ komputer jika aplikasinya didownload dengan bantuan jaringan internet. Agar bisa bersosial melalui media sosial atau tanpa harus bertatap muka, maka harus memiliki akun terlebih dahulu dengan mendaftarkan diri. Dalam proses mendaftarkan diri, dibutuhkan data pribadi seperti nama dan alamat email. Hampir semua orang yang memiliki smartphone, memiliki media sosial bahkan mereka tidak hanya memiliki satu media sosial. Hal demikian yang 
membuat persebaran meme melalui media sosial sangat cepat, banyak, dan meluas atau sering disebut viral. Pada akhirnya, meme menjadi tren masa kini bagi kalangan remaja dan dewasa. Adanya penyebaran meme yang viral, menjadikan para peneliti tertarik untuk menelitinya.

Lokasi meme yang dipilih yaitu pada akun instagram. Hal ini dikarenakan instagram adalah sebuah aplikasi berbagi foto dan meme merupakan wujud karya berupa gambar/foto (visual) yang diberi tulisan (verbal). Nama akun instagram yang dipilih adalah Dagelan_ Jowo. Hal ini dikarenakan akun tersebut sebagian besar terdapat unggahan meme berbahasa Jawa dan meme-meme tersebut mengandung aspek-aspek yang dibutuhkan dalam penelitian ini. Selain itu, jumlah follower (pengikut) yang cukup banyak (yaitu sekitar 336.000 follower) dibanding dengan akun instagram lain yang juga mengunggah meme berbahasa Jawa.

Berdasarkan latar belakang di atas, maka rumusan masalah dalam penelitian ini adalah sebagai berikut: a) Bagaimanakah bentuk-bentuk bahasa Jawa yang digunakan dalam meme berbahasa Jawa?; b) Bagaimanakah bentuk-bentuk meme berbahasa Jawa?; c) Bagaimanakah fungsi meme berbahasa Jawa terhadap masyarakat pembacanya?

Menurut Rosa Redia Pusanti dan Haryanto (2015, p.5), new media adalah sebuah yang masuk ke dalam ranah studi komunikasi, khususnya sebagai medium dari komunikasi massa. New media merupakan studi tentang sebuah medium komunikasi yang secara luas terintegrasi ke dalam sebuah jaringan atau internet atau media elektronik. Melalui gagasan the second media age, Mark Poster menegaskan adanya periode baru dimana teknologi interaktif dan komunikasi interaktif, khususnya internet, akan mampu mengubah masyarakat. New Media Theory juga menegaskan dua pandangan dominan tentang perbedaan-perbedaan antara the first media yang menekankan pada siaran (seperti radio dan televisi) dengan the second media yang menekankan pada jejaring (seperti media sosial). Maka dapat disimpulkan bahwa media baru diindikasikan dengan adanya digitalisasi dari semua aspek media yang tidak terkendala oleh lokasi dan waktu. Peran utama dalam perubahan-perubahan yang terjadi melalui media baru ialah adanya peran teknologi elektronik terutama internet dalam persebaran pesan-pesan di dunia maya.

\subsection{Social Media}

Menurut Rosa Redia Pusanti dan Haryanto (2015, p.6) social media di Indonesia sendiri telah berkembang sejak kemunculan "Friendster", "Facebook", "Twitter" dan kemudian disempurnakan oleh kehadiran "Path". Sebagai negara berkembang, Indonesia menjadi negara dengan kebutuhan internet yang cukup tinggi dengan keaktifan yang terbilang luar biasa karena menempati setidaknya urutan ke 4 sebagai pengguna "Facebook" serta "Twitter" terbanyak di tahun 2013 dan selalu memasuki jajaran 5 besar dalam jumlah pengguna "Path" hingga di akhir tahun 2014.

Pada bulan Juli 2012 dua kota besar di Indonesia, Jakarta dan Bandung menempati 10 besar dengan kesibukan percakapan di "Twitter" bahkan menempati urutan pertama mangalahkan New York, Tokyo, London dan Sao Paulo seperti yang dirilis oleh Forbes berdasarkan analisis akun dan kicauan "Twitter". Hal ini tentu menunjukkan keaktifan netizen di Indonesia dalam menggunakan internet, apalagi dalam fungsinya untuk berbagi dalam ruang lebih pribadi, yaitu melalui "Path". Kecenderungan percakapan di social media di Indonesia memang masih sebagian besar terkait pesan-pesan ringan, yaitu sekitar $80 \%$ dan 20\% telah memanfaatkan social media untuk promosi bisnis dan politik (Rosa Redia Pusanti dan Haryanto, 2015, p.6). 


\subsection{Instagram}

Instagram berasal dari kata 'instan' atau 'insta' dan 'gram' yang berasal dari kata 'telegram'. Hal ini dikarenakan, Instagram ialah cara untuk berfoto dan membagikan foto kepada orang lain secara mudah dan instan, sedangkan telegram merupakan media yang sangat cepat dalam mengirimkan informasi kepada seseorang. Instagram ialah suatu jejaring sosial yang mempunyai tujuan untuk membantu penggunanya untuk membagikan foto kepada pengguna lainnya. Instagram masih berkhusus kepada pengguna Android, Iphone, Ipod, Ipad, dan Gadget yang mempunyai OS 3.2 (Taufiq Rahman, 2014).

\subsection{Meme}

Menurut John Paull (2009, p.12) memetics remains an immature discourse which is potentially valuable for considering the diffusion of elements of culture and the underlying evolution, dissemination and "natural history" of those elements (mimetic menyisakan sebuah wacana yang belum matang yang berpotensi berharga sebagai pertimbangan penyebaran dari elemen budaya dan mendasari evolusi, penyebaran, dan sejarah alami dari elemen), sedangkan menurut Christian Bauckhage (2011), meme biasanya berkembang melalui komentar, imitasi, parodi, atau bahkan hasil pemberitaan di media.

Menurut Limor Shiftman (2013, p.364-365), three main attributes ascribed to memes are of particular relevance to the analysis of contemporary digital culture. First, memes may best be understood as cultural information that passes along from person to person, yet gradually scales into a shared social phenomenon. A second attribute of memes is that they reproduce by various means of imitation. A third attribute of memes that makes them appealing for scholars interested in digital culture is their diffusion through competition and selection (tiga jenis atribut yang berperan pada meme adalah hubungan khusus untuk analisis budaya digital kontemporer. Pertama, meme mungkin dipahami sebagai informasi budaya melalui orang ke orang, yang secara berangsur-angsur dibagikan menjadi femonena sosial. Kedua, mereka menghasilkan makna yang beraneka ragam atas adanya bentuk peniruan, Ketiga, menarik bagi penikmat di budaya digital yang disebarkan melalui kompetisi dan tahap pemilihan).

Berdasarkan definisi di atas, bahwa meme adalah fenomena peniruan yang mengandung ide, simbol, perilaku, gaya, praktik dalam budaya yang diwujudkan dalam tulisan, ucapan, gerak tubuh, ritual, atau fenomena lain yang dapat ditiru, kemudian perwujudan itu ditularkan dari orang ke orang. Ada 4 poin yang ada di meme, antara lain: 1) fenomena peniruan; 2) mengandung ide, simbol, perilaku, gaya, praktik dalam budaya; 3) diwujudkan dalam tulisan, ucapan, gerak tubuh, ritual, atau fenomena lain yang dapat ditiru; 4) ditularkan dari orang ke orang.

Jenis-jenis meme yang tersebar di internet ada sekitar 55 jenis (trollface, yuno, me gusta, dan lain-lain). Penyebaran meme tersebut secara viral, berwujud asli ataupun turunannya/ sudah dimodifikasi.

Diksi/pilihan kata adalah kemampuan membedakan secara tepat nuansa-nuansa makna dari gagasan yang ingin disampaikan, dan kemampuan untuk menemukan bentuk yang sesuai (cocok) dengan situasi dan nilai rasa yang dimiliki kelompok masyarakat pendengar. Pilihan kata yang tepat dan sesuai hanya dimungkinkan oleh penguasaan sejumlah besar kosakata atau perbendaharaan kata bahasa itu. Pilihan kata atau diksi mencakup pengertian kata-kata mana yang dipakai untuk menyampaikan suatu gagasan, bagaimana membentuk pengelompokan kata-kata yang tepat atau menggunakan ungkapan-ungkapan yang tepat, dan gaya mana yang paling baik digunakan dalam suatu situasi (Gorys Keraf, 2002, p.24). 
Diksi digunakan untuk menyatakan kata-kata yang dipakai untuk mengungkapkan suatu ide atau gagasan, yang meliputi persoalan frasaologi, gaya bahasa, dan ungkapan (Teguh Supriyanto, 2011, p.32). Diksi adalah pilihan kata yang tepat dan selaras (contoh penggunaannya) untuk mengungkapkan gagasan sehingga memperoleh efek tertentu (seperti yang diharapkan) (Departemen Pendidikan dan Kebudayaan, 1996, p. 233). Diksi adalah pilihan kata dan kejelasan lafal untuk memperoleh efek tertentu dalam berbicara di depan umum atau dalam karang-mengarang (Harimurti Kridalaksana, 2008, p.50).

Pemilihan kata merupakan salah satu aspek yang penting dalam berbahasa karena pemilihan kata akan: (1) mempercepat pengungkapan gagasan, (2) menjadikan bahasa yang digunakan menjadi lebih hidup, (3) menarik dan tidak membosankan, serta (4) menghindari salah informasi (S.S.T. Wisnu Sasangka, 2013, p.97).

Berdasarkan pendapat para ahli mengenai pengertian diksi, maka dapat disimpulkan bahwa diksi adalah pemilihan dan pemakaian kata yang tepat sesuai dengan kebutuhan untuk mencapai efek-efek tertentu.

Jenis diksi menurut Gorys Keraf (2000, p.89-108) adalah denotasi, konotasi, kata abstrak, kata konkret, kata umum, kata khusus, kata ilmiah, kata populer, jargon, kata slang, kata asing, dan kata serapan. Denotasi adalah makna kata sebenarnya, misalnya: bunga. Konotasi adalah makna kias atau makna bukan sebenarnya, misalnya: kampung halaman 'daerah kelahiran'. Kata abstrak adalah kata yang mempunyai referen berupa konsep, misalnya: luput ' tidak tepat sasaran/ tidak sesuai'. Kata konkret adalah kata yang mempunyai referen yang dapat dilihat oleh panca indera secara langsung, misalnya: wedhak 'bedak'. Kata umum adalah kata yang mempunyai cakupan atau ruang lingkup yang luas, misalnya: hewan. Kata khusus adalah kata yang mempunyai cakupan secara khusus, misalnya: pitik 'ayam'. Kata ilmiah adalah kata yang dipakai oleh kaum terpelajar, terutama dalam tulisantulisan ilmiah. Kata populer adalah kata yang dipakai oleh semua lapisan masyarakat, misalnya: maido 'menyepelekan'. Jargon adalah kata-kata teknis pada bidang ilmu tertentu, misalnya: UKM (Unit Kegiatan Mahasiswa). Kata slang adalah kata-kata non-standar dan informal, misalnya: alay 'orang yang berlebihan/tidak sewajarnya'. Kata asing adalah kata yang berasal dari bahasa asing, misalnya: update 'terkini'. Kata serapan adalah kata dari bahasa asing atau bahasa Indonesia yang sudah diserap ke dalam bahasa Jawa, misalnya: kampanye 'kampanye'.

Bahasa Jawa memiliki tingkat tutur. Bahasa Jawa ragam krama adalah tingkat tutur yang tertinggi dalam bahasa Jawa. Soepomo Poedjisoedarmo (dalam Marmanto, 2010, p.25) membagi tingkat tutur menjadi tiga jenis, yaitu (1) tingkat tutur krama, (2) tingkat tutur madya, (3) tingkat tutur ngoko.

\section{Metode Penelitian}

Penelitian ini adalah penelitian deskriptif kualitatif. Sumber data berupa dokumen yaitu 3 meme berbahasa Jawa yang diperoleh dari akun instagram Dagelan_Jowo. Penentuan sampel dalam penelitian ini menggunakan teknik purposive sampling yaitu pengambilan sampel yang disesuaikan dengan tujuan penelitian (Siswantoro, 2010, p.73).

Metode pengumpulan data yaitu dengan metode simak dengan teknik pustaka dan teknik catat, serta wawancara. Metode analisis data dengan menggunakan metode padan. Metode padan adalah metode analisis data yang alat penentunya di luar, terlepas dan tidak menjadi bagian dari bahasa (langue) yang bersangkutan (Sudaryanto, 1993, p.13). 


\section{Hasil dan Pembahasan}

Meme berbahasa Jawa ini memiliki dua variasi bentuk yaitu monolog dan dialog. Monolog adalah percakapan seorang diri. Jadi, meme menggambarkan seseorang yang sedang berkata sendiri dengan didukung oleh gambar yang ada. Sedangkan berupa dialog adalah percakapan antara dua orang atau lebih dan juga dengan didukung oleh gambar. Berikut ini, adalah contoh meme berbentuk monolog.

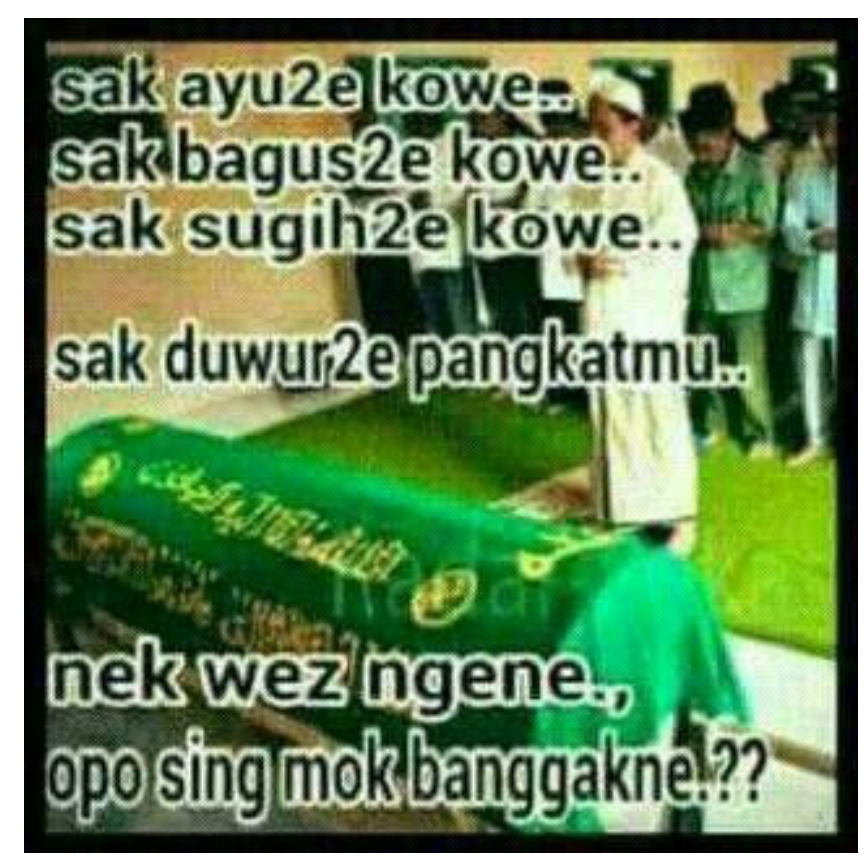

Gambar 1. Data meme

Bahasa Jawa secara tingkatan dibedakan menjadi dua yaitu ragam ngoko dan krama. Ragam ngoko biasanya dipakai oleh orang yang seumuran atau digunakan kepada orang yang lebih muda. Sedangkan ragam krama digunakan oleh orang yang seumuran (memiliki jabatan yang tinggi) atau digunakan kepada yang lebih tua dengan fungsi untuk menghormati. Meme di atas menggunakan bahasa Jawa ragam ngoko. Ragam ngoko tersebut menunjukkan bahwa pembuat meme ini menempatkan memenya sebagai sesuatu yang umum dan bersifat netral.

Dilihat dari diksi yang dipakai, pembuat meme menggunakan singkatan dengan ditandai angka 2 dalam ayu2ne, bagus2e, sugih2e, dan duwur2e. Hal demikian berfungsi untuk mengefektifkan ruang meme tersebut agar tidak terlalu panjang dan efektif, meskipun hal tersebut tidak sesuai dengan Ejaan Yang Disempurnakaan. Penggunaan kata wez, seharusnya wis, huruf z pada kata tersebut menunjukkan kreatifitas si pembuat meme, sedangkan huruf e merupakan kesalahan dikarenakan kurang pahaman pembuat meme terhadap penulisan bahasa Jawa. Terlihat pula dalam kata opo seharusnya apa.

Meme tersebut memiliki tema sosial karena dekat dengan kehidupan sehari-hari yaitu tentang kematian. Dalam hidup bermasyarakat, pasti akan menemui peristiwa kematian. Kematian ini sering ditakutkan oleh manusia. Dalam hal ini, meme tersebut memiliki fungsi peringatan. Meme tersebut memiliki pesan agar ingat akan kematian dan tidak bangga dan sombong dengan gebyarnya dunia (kecantikan, ketampanan, kekayaan, pangkat yang tinggi), karena gebyarnya dunia akan tidak ada apa-apanya lagi setelah menemui kematian. Gambar peti jenazah dan orang yang sedang menyolatkan jenazah dengan khusyuk tersebut sangat mendukung dan sesuai dengan kata-kata (verbal) yang ada. 


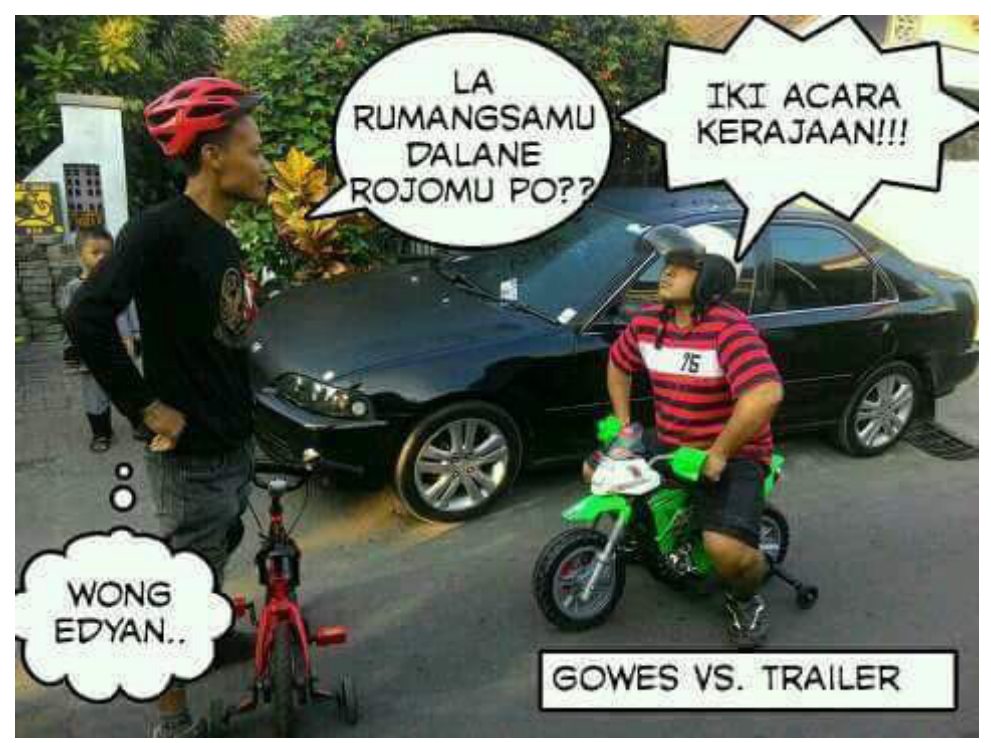

Gambar 2. Data meme

Meme tersebut berupa dialog antara dua orang antara pengendara sepeda dengan pengendara motor. Hal tersebut bersifat menghibur, karena sepeda yang digunakan adalah sepeda anak-anak bentuknya kecil dan motor kecil. Seolah-oleh sepeda dan motor itu hanya simbol saja karena bentuknya kecil. Bahasa yang digunakan menggunakan bahasa Jawa ragam ngoko yang berupa percakapan. Ragam ngoko di sini bersifat netral dan umum. Dilihat dari penggunaan diksi, kata rojomu seharusnya rajamu dan kata po seharusnya $p a$. Hal demikian menunjukkan kurangnya pengetahuan pembuat meme tentang tata cara penulisan dalam bahasa Jawa.

Meme tersebut bertema sosial, karena ditemui dalam kehidupan sehari-hari yaitu mengendarai kendaraan dan berpapasan dengan pengendara lain. Selain bersifat menghibur, juga memiliki fungsi sebagai sindiran yaitu sindiran terhadap para pengendara motor yang ugal-ugalan, ingin menang sendiri, dan tidak peduli terhadap pengendara lain. Pengendara sepeda marah ketika pengendara motor melewati jalan dengan ugal-ugalan dan seakan-akan jalan yang dilewati merupakan jalannya sendiri dan menggunakan jalan dengan seenaknya.

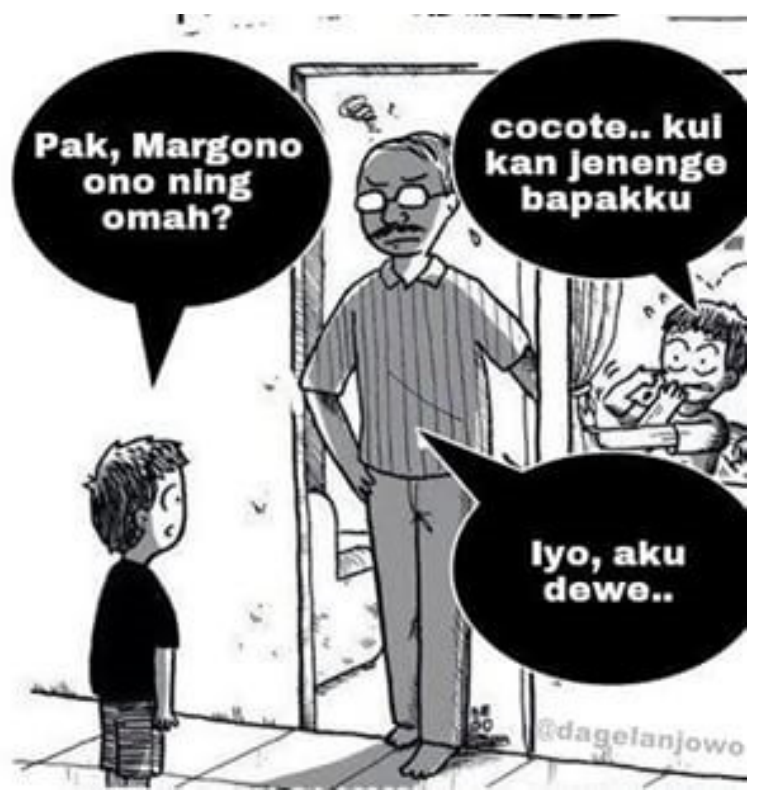

Gambar 3. Data meme 
Meme tersebut berupa meme dialog yang dilakukan oleh 3 orang yaitu tamu, bapak, dan anak. Ragam yang digunakan adalah ragam ngoko. Tamu yang usianya sepantaran dengan anak memakai ragam ngoko. Hal ini menunjukkan anak tersebut kurang sopan dan tidak menghormati bapak tersebut. Selain itu, anak yang di dalam rumah menggunakan diksi kasar cocote yang artinya mulutnya. Kemudian bapak tersebut dengan ekspresi marah karena bapak merasa tidak dihormati. Nampak terjadi kesalahpahaman, seharusnya tamu tersebut mengucapkan "Pak Margono ana ning omah?", tidak ada koma antara pak dan Margono, karena nama margono dikira nama anak bapak itu ternyata nama bapak itu. Dan akibat dari kesalahpahaman itu, akhirnya anak yang di dalam rumah misuh atau mengeluarkan kata-kata kasar.

Diksi ono seharusnya ditulis ana, dan kata iyo seharusnya ditulis iya. Hal tersebut menunjukkan kurang pemahaman pembuat meme dalam penulisan bahasa Jawa. Meme tersebut bertema sosial karena merupakan perilaku sehari-hari yaitu kegiatan bertamu. Dalam hidup bermasyarakat, pasti melakukan kegiatan bertamu ini. Dari segi fungsi meme, meme ini berfungsi untuk menyindir bahwasannya saat ini banyak anak/pemuda yang tidak sopan terhadap orang tua, dalam meme itu terlihat dalam pemakaian bahasanya. Pemakaian bahasa tamu yang tidak menggunakan ragam krama kepada bapak itu, padahal bapak itu lebih tua.

\section{Simpulan}

Meme berbahasa Jawa merupakan salah satu wujud pemertahanan bahasa Jawa yang ada saat ini, di era yang serba internet ini. Bentuk ekspresif dari pembuat meme menjadi hiburan sekaligus penuh dengan pesan dan meta pesan yang ingin disampaikan si pembuat kepada pembaca meme. Meme yang merupakan paduan utuh antara visual dan verbalnya menjadi kesatuan yang mampu memunculkan tawa pembaca. Meme tersebut merupakan representasi aktivitas manusia sehari-hari sehingga banyak bertemakan sosial. Karena banyak bertema sosial, maka ragam bahasa yang digunakan adalah bahasa Jawa ragam ngoko yang dominan bersifat netral.

\section{Daftar Pustaka}

Bauckhage, Christian. (2011). "Insight into Internet Memes". Proceedings of the Fifth International AAAI Conference on Weblogs and Social Media, hlm. 42-49.

Departemen Pendidikan dan Kebudayaan. (1996). Kamus Besar Bahasa Indonesia: Edisi Kedua. Jakarta: Balai Pustaka.

Gorys Keraf. (2002). Diksi dan Gaya Bahasa. Jakarta: PT Gramedia Pustaka Utama.

Harimurti Kridalaksana. (2008). Kamus Linguistik: Edisi Keempat. Jakarta: PT Gramedia Pustaka Utama.

Henky Prihatna. (2005). Kiat Praktis Menjadi Webmaster Profesional. Jakarta: PT Elex Media Komputindo.

John Paull. (2009). Meme Maps: A Tool for Configuring Memes in Time and Space. European Journal of Scientific Research, vol. 31, no. 1, hlm 11-18.

Kenfitria Diah Wijayanti. (2015). Meta Pesan dalam Perspektif Meme. Hlm. 203-207. Kajian Pragmatik dalam Berbagai Bidang. UNS Press. Surakarta.

Pratiwi Wini. (2012). Bahasa Jawa Peringkat ke-11 Dunia, www.winipedia127607. wordpress.com. Diakses pada tanggal 11 Agustus, pukul 15.50 WIB. 
Rosa Redia Pusanti dan Haryanto. (2015). Representasi Kritik dalam Meme Politik (Studi Semiotika Meme Politik dalam Masa Pemilu 2014 pada Jejaring Sosial "Path" sebagai Media Kritik di Era Siber). Jurnal Komunikasi Massa UNS, Universitas Sebelas Maret, Vol.1 edisi 2015.

Shiftman, L. (2013). Memes in a Digital World: Reconciling with a Conceptual Troublemaker. Journal of Computer-Mediated Communication 2013, hlm.362.

Siswantoro. (2010). Metode Penelitian Sastra. Yogyakarta: Pustaka Pelajar.

Sri Marmanto. (2012). Pelestarian Bahasa Jawa Krama di Kota Surakarta. Surakarta: UNS Press.

Sry Satriya Tjatur Wisnu Sasangka. 2013. Jendela Bahasa Indonesia. Yogyakarta: Almatera Publishing.

Sudaryanto. (1993). Metode dan Aneka Teknik Analisis Bahasa: Pengantar Penelitian Wahana Kebudayaan secara Linguistik. Yogyakarta: Duta Wacana University Press.

Taufiq Rahman. (2014). Pengertian Instagram Lengkap. https://rahman371.wordpress. com/2014/09/06/pengertian-instagram-lengkap/). Diakses pada tanggal 11 Agustus 2016, pukul 14.59 WIB. 